\title{
Molecular Study of Pyruvate Kinase Deficient Patients with Hereditary Nonspherocytic Hemolytic Anemia
}

\author{
Luciano Baronciani and Ernest Beutler \\ Department of Molecular and Experimental Medicine, The Scripps Research Institute, La Jolla, California 92037
}

\begin{abstract}
DNA analysis was performed on 30 unrelated patients with hereditary nonspherocytic hemolytic anemia (HNSHA) who had been found to be pyruvate kinase (PK) deficient by enzyme assay. 19 different mutations were identified among 58 of the 60 alleles at risk. 13 of these were missense mutations that caused single amino acid changes. Included were the following nucleotide substitutions: 401A, 464C, 993A, 1022C, 1076A, 1178G, 1179A, 1373A, 1378A, 1456T, 1484T, 1493A, 1529A. The remaining six mutations were as follows: two nonsense mutations, $721 \mathrm{~T}$ and 808T; a nucleotide deletion, 307C; a nucleotide insertion, 1089GG; a three nucleotide in frame deletion, 391-392-393 and a deletion of 1149 bp from the $P K L R$ gene that resulted in the loss of exon 11. All the patients were studied for two polymorphic sites, nucleotide (nt) $1705 \mathrm{~A} / \mathrm{C}$ and a microsatellite in intron 11, to better understand the origin of the mutations. The 1529A mutation, which is the most common mutation in the European population, was found in $\mathbf{2 5}$ alleles. With a single exception this mutation was in linkage disequilibrium with both of the polymorphic markers, i.e., found with $1705 \mathrm{C}$ and 14 repeats in the microsatellite. This finding is consistent with a single origin of this common mutation. Other mutations occurring more than once were of much lower frequency than the 1529A mutation. (J. Clin. Invest. 1995. 95:1702-1709.) Key words: mutation • polymorphism • microsatellite $\cdot$ haplotype
\end{abstract}

\section{Introduction}

Pyruvate kinase $(\mathrm{PK})^{1}$ is a ubiquitous enzyme that plays an important role in the glycolytic pathway. Two different PK genes are present in mammals, $P K L R$ coding for the liver (L) and red cell (R) isoenzymes and $P K M$, coding for the M1 and M2 isoenzymes (1). The PKLR gene is organized into 12 exons. The first and the second exons are specifically transcribed respectively to the R and the L-type PK mRNA by two different tissue-specific promoters (2).

Address correspondence to E. Beutler, Dept. of Molecular and Experimental Medicine, The Scripps Research Institute, 10666 North Torrey Pines Rd., La Jolla, CA 92037. Phone: 619-554-8040; FAX: 619-5546927.

Received for publication 9 September 1994 and in revised form 29 November 1994

1. Abbreviations used in this paper: HNSHA, hereditary nonspherocytic hemolytic anemia; PK, pyruvate kinase.

J. Clin. Invest.

(c) The American Society for Clinical Investigation, Inc. 0021-9738/95/04/1702/08 \$2.00

Volume 95, April 1995, 1702-1709
In the erythrocyte only one of the two products of the $P K L R$ gene is normally expressed, the R-type (3). PK deficiency is the single most common cause of hereditary nonspherocytic hemolytic anemia (HNSHA). HNSHA due to pyruvate kinase deficiency was first described in 1961 (4). By 1983 more than 300 cases had been reported (5). The clinical symptoms are variable, ranging from cases of pronounced neonatal jaundice requiring multiple exchange transfusions, to a fully compensated hemolytic anemia. In some cases PK deficiency can be fatal in early childhood. Splenectomy is effective in decreasing hemolysis in most of the patients (1).

In 1979 the International Committee for Standardization in Hematology established standard methods for characterizing PK variants so that it would be possible to compare results from different laboratories (6). However, many difficulties still arise when enzymologic methods are used for either diagnosis or enzyme characterization. Because of the low activity and stability of the mutant enzyme, more blood may be required than is readily available. In transfusion-dependent patients samples are contaminated with transfused, normal erythrocytes. The product of the $P K M$ gene present in leukocytes may also confuse the results. Interpretation of the biochemical properties of the residual enzyme is made difficult or impossible in compound heterozygotes by the formation of hybrid enzymes with different biochemical properties.

The cloning of the R-type cDNA has enabled us to study this enzyme deficiency at the DNA level $(7,8)$. Sequence analysis has also made it possible to establish diagnoses and to determine to what extent variants occurring in different patients actually differed. Previously, we determined the sequence of the introns flanking all 12 exons of the $P K L R$ gene and using a PCR-based technology we documented eight mutations in PK deficient patients from genomic DNA (9). In this investigation we describe the results in all thirty patients affected with PK deficiency that we have studied to date. Some of these have recently been reported in abstracts $(10,11)$.

\section{Methods}

Patients. Patients with HNSHA were screened by assay of erythrocyte enzymes, as reported previously (12). Table I presents the ethnic origin and enzymologic data pertaining to the PK deficient patients. Patients 6 and 27 were transfused shortly before blood was drawn. In spite of the transfusion, the red cells of patient 6 had low PK activity, but those of patient 27 had high activity and the diagnosis of PK deficiency was established only after performing red cell PK assays on the mother and sister of the patient. The results of mutation analysis in some of these patients have been reported earlier (9), as indicated in Table I. They are included in the present report to provide a more comprehensive account of the mutations we have identified.

Nomenclature. The different nomenclatures that have been used to identify the exons of the PKLR gene are shown in Fig. 1. Mutations are designated using the type-R cDNA sequence, with the $A$ of the initiation ATG being assigned number 1 . Amino acids are numbered from the first methionine of the deduced R-type enzyme. 
Table I. Characteristics of Patients with Hemolytic Anemia Due to PK Deficiency

\begin{tabular}{|c|c|c|c|c|c|c|c|c|}
\hline Patient & Ethnic origin & $\begin{array}{l}\text { PK activity, } \\
V_{\max } \text { in } \mathrm{IU} \\
\text { per } \mathrm{g} \text { of } \mathrm{Hb}\end{array}$ & $\begin{array}{l}\text { Low } S \% \\
\text { of } V_{\max }{ }^{*}\end{array}$ & $\begin{array}{c}\text { Low } S+ \\
\text { FDP } \% \text { of } \\
V_{\max }\end{array}$ & Mutation (cDNA nt) & Amino acid substitution & nt 1705 & $\begin{array}{l}\text { Microsatellite } \\
\text { ATT repeat }\end{array}$ \\
\hline 1 & U.S. white* & 4 & 51.9 & 57.6 & $1484 \mathrm{C} \rightarrow \mathrm{T} / 1529 \mathrm{G} \rightarrow \mathrm{A}$ & Ala495 $\rightarrow$ Val/Arg510 $\rightarrow$ Gln & $\mathrm{C} / \mathrm{C}$ & $15 / 14$ \\
\hline 2 & U.S. white & 4.28 & 31.2 & 31.2 & $1456 \mathrm{C} \rightarrow \mathrm{T} / 1178 \mathrm{~A} \rightarrow \mathrm{G}$ & Arg486 $\rightarrow$ Trp/Asn393 $\rightarrow$ Ser & $\mathrm{C} / \mathrm{C}$ & $14 / 14$ \\
\hline 3 & U.S. white* & 2.5 & 22.8 & 40 & $1529 \mathrm{G} \rightarrow \mathrm{A} / 1529 \mathrm{G} \rightarrow \mathrm{A}$ & $\operatorname{Arg} 510 \rightarrow \operatorname{Gln} / \operatorname{Arg} 510 \rightarrow \mathrm{Gln}$ & $\mathrm{C} / \mathrm{C}$ & $14 / 14$ \\
\hline 4 & U.S. white* & 2.8 & 38.5 & 64.5 & $1529 \mathrm{G} \rightarrow \mathrm{A} / 1529 \mathrm{G} \rightarrow \mathrm{A}$ & $\operatorname{Arg} 510 \rightarrow$ GlnArg510 $\rightarrow$ Gln & $\mathrm{C} / \mathrm{C}$ & $14 / 14$ \\
\hline 5 & U.S. white* & 3.8 & 18.4 & 42.9 & $1529 \mathrm{G} \rightarrow \mathrm{A} / 464 \mathrm{~T} \rightarrow \mathrm{C}$ & Arg510 $\rightarrow$ Gln/Leu $155 \rightarrow$ Pro & $\mathrm{C} / \mathrm{C}$ & $14 / 12$ \\
\hline 6 & Gypsy & 9.1 & 9.3 & 39 & del exon 11/del exon 11 & NA/NA & $\mathrm{C} / \mathrm{C}$ & $15 / 15$ \\
\hline 7 & U.S. white* & 1.9 & 4 & 16 & $1484 \mathrm{C} \rightarrow \mathrm{T} / 1529 \mathrm{G} \rightarrow \mathrm{A}$ & Ala495 $\rightarrow$ Val/Arg510 $\rightarrow$ Gln & $\mathrm{C} / \mathrm{C}$ & $15 / 14$ \\
\hline 8 & U.S. white* & 2.71 & 11.4 & 47.1 & $1456 \mathrm{C} \rightarrow \mathrm{T} / 401 \mathrm{~T} \rightarrow \mathrm{A}$ & Arg $486 \rightarrow$ Trp/Val134 $\rightarrow$ Asp & $\mathrm{C} / \mathrm{C}$ & $15 / 16$ \\
\hline 9 & Gypsy & 2.55 & 30.8 & 50 & del exon 11/del exon 11 & NA/NA & $\mathrm{C} / \mathrm{C}$ & $15 / 15$ \\
\hline 10 & U.S. African* & 4.1 & 15.6 & 56.9 & $1076 \mathrm{G} \rightarrow \mathrm{A} / 11$ & Arg359 $\rightarrow$ His/l" & $\mathrm{A} / \mathrm{A}$ & $12 / 13$ \\
\hline 11 & Canadian white* & 1.9 & 28.6 & 42.9 & $1529 \mathrm{G} \rightarrow \mathrm{A} / 1089 \mathrm{G} \rightarrow \mathrm{GG}$ & $\operatorname{Arg} 510 \rightarrow \mathrm{Gln} / \mathrm{NA}$ & $\mathrm{C} / \mathrm{A}$ & $14 / 13$ \\
\hline 12 & U.S. white* & 7.6 & 7.6 & 25.4 & $391-393 \mathrm{del} / 721 \mathrm{G} \rightarrow \mathrm{T}$ & Ile131 $\rightarrow$ del/Glu241 $\rightarrow$ End & $\mathrm{C} / \mathrm{C}$ & $15 / 14$ \\
\hline 13 & U.S. white & 4.06 & 25.74 & 53.47 & $1529 \mathrm{G} \rightarrow \mathrm{A} / 721 \mathrm{G} \rightarrow \mathrm{T}$ & Arg510 $\rightarrow$ Gln/Glu241 $\rightarrow$ End & $\mathrm{C} / \mathrm{C}$ & $14 / 14$ \\
\hline 14 & U.S. white & 1.91 & 21 & 21 & $307 \mathrm{C} \mathrm{del} / 1378 \mathrm{G} \rightarrow \mathrm{A}$ & NA/Val460 $\rightarrow$ Met & $\mathrm{A} / \mathrm{C}$ & $12 / 16$ \\
\hline 15 & U.S. white & 5.18 & 25.6 & 38.6 & $1456 \mathrm{C} \rightarrow \mathrm{T} / 1493 \mathrm{G} \rightarrow \mathrm{A}$ & Arg486 $\rightarrow$ Trp/Arg498 $\rightarrow$ His & $\mathrm{C} / \mathrm{A}$ & $14 / 13$ \\
\hline 16 & U.S. white & 6.85 & 14.19 & 48.62 & $1529 \mathrm{G} \rightarrow \mathrm{A}^{\prime \prime}$ & Arg5 $10 \rightarrow \mathrm{Gln} / ?$ & $\mathrm{C} / \mathrm{C}$ & $14 / 15$ \\
\hline 17 & U.S. white & 5.75 & 18.2 & 45.5 & $1529 \mathrm{G} \rightarrow \mathrm{A} / 1529 \mathrm{G} \rightarrow \mathrm{A}$ & $\operatorname{Arg} 510 \rightarrow$ Gln/Arg510 $\rightarrow$ Gln & $\mathrm{C} / \mathrm{C}$ & $14 / 14$ \\
\hline 18 & U.S. white & 7.73 & 14.4 & 46.5 & $1456 \mathrm{C} \rightarrow \mathrm{T} / 1179 \mathrm{~T} \rightarrow \mathrm{A}$ & Arg486 $\rightarrow$ Trp/Asn393 $\rightarrow$ Lys & $\mathrm{A} / \mathrm{C}$ & $14 / 14$ \\
\hline 19 & U.S. white & 6.22 & 24.6 & 61.4 & $1529 \mathrm{G} \rightarrow \mathrm{A} / 1373 \mathrm{G} \rightarrow \mathrm{A}$ & Arg510 $\rightarrow$ Gln/Gly458 $\rightarrow$ Asp & $\mathrm{C} / \mathrm{C}$ & $14 / 13$ \\
\hline 20 & U.S. white & 8.4 & 15.1 & 42 & $1529 \mathrm{G} \rightarrow \mathrm{A} / 721 \mathrm{G} \rightarrow \mathrm{T}$ & Arg510 $\rightarrow$ Gln/Glu241 $\rightarrow$ End & $\mathrm{C} / \mathrm{C}$ & $14 / 14$ \\
\hline 21 & U.S. white & 5.86 & 7.78 & 39.28 & $1529 \mathrm{G} \rightarrow \mathrm{A} / 808 \mathrm{C} \rightarrow \mathrm{T}$ & Arg510 $\rightarrow$ Gln/Arg270 $\rightarrow$ End & $\mathrm{C} / \mathrm{C}$ & $14 / 14$ \\
\hline 22 & U.S. white & 2.51 & 40 & 60 & $1529 \mathrm{G} \rightarrow \mathrm{A} / 1529 \mathrm{G} \rightarrow \mathrm{A}$ & Arg510 $\rightarrow$ Gln/Arg510 $\rightarrow$ Gln & $\mathrm{C} / \mathrm{C}$ & $14 / 14$ \\
\hline 23 & U.S. white & 2.57 & 26.3 & 47.4 & $1529 \mathrm{G} \rightarrow \mathrm{A} / 1529 \mathrm{G} \rightarrow \mathrm{A}$ & $\operatorname{Arg} 510 \rightarrow$ Gln/Arg510 $\rightarrow$ Gln & $\mathrm{C} / \mathrm{C}$ & $14 / 15$ \\
\hline 24 & U.S white & 2.8 & 29.7 & 66.2 & $1529 \mathrm{G} \rightarrow \mathrm{A} / 993 \mathrm{C} \rightarrow \mathrm{A}$ & Arg510 $\rightarrow$ Gln/Asp331 $\rightarrow$ Glu & $\mathrm{C} / \mathrm{C}$ & $14 / 14$ \\
\hline 25 & U.S. white & 1.6 & 10 & 45 & $1484 \mathrm{C} \rightarrow \mathrm{T} / 1529 \mathrm{G} \rightarrow \mathrm{A}$ & Ala495 $\rightarrow$ Val/Arg510 $\rightarrow$ Gln & $\mathrm{C} / \mathrm{C}$ & $14 / 15$ \\
\hline 26 & U.S. white & 2.5 & 23.3 & 50 & $1529 \mathrm{G} \rightarrow \mathrm{A} / 1529 \mathrm{G} \rightarrow \mathrm{A}$ & $\operatorname{Arg} 510 \rightarrow \operatorname{Gln} / \operatorname{Arg} 510 \rightarrow$ Gln & $\mathrm{C} / \mathrm{C}$ & $14 / 14$ \\
\hline 27 & U.S. white & 16.6 & 8.42 & 45.31 & $1456 \mathrm{C} \rightarrow \mathrm{T} / 1022 \mathrm{G} \rightarrow \mathrm{C}$ & Arg486 $\rightarrow$ Trp/Gly341 $\rightarrow$ Ala & $\mathrm{C} / \mathrm{C}$ & $14 / 14$ \\
\hline 28 & Hispanic & 1.65 & 16.66 & 51.3 & $1378 \mathrm{G} \rightarrow \mathrm{A} / 1378 \mathrm{G} \rightarrow \mathrm{A}$ & Val460 $\rightarrow$ Met/Val460 $\rightarrow$ Met & $\mathrm{C} / \mathrm{C}$ & $16 / 16$ \\
\hline 29 & Gypsy & 2.21 & 36.4 & 50 & del exon 11/del exon 11 & NA/NA & $\mathrm{C} / \mathrm{C}$ & $15 / 15$ \\
\hline 30 & U.S. white & 1.25 & 29.4 & 47.1 & $1529 \mathrm{G} \rightarrow \mathrm{A} / 1529 \mathrm{G} \rightarrow \mathrm{A}$ & Arg510 $\rightarrow$ Gln/Arg510 $\rightarrow$ Gln & $\mathrm{C} / \mathrm{C}$ & $14 / 14$ \\
\hline Normal & mean $\pm S D$ & $15.0 \pm 2.0$ & $16.6 \pm 7.9$ & $45.8 \pm 7.9$ & & & & \\
\hline
\end{tabular}

* Reported previously (9). ${ }^{\ddagger}$ Assay carried out at low substrate concentration (12). ${ }^{\S}$ Assay carried out at low substrate concentration and added fructose diphosphate (12). "Whole coding sequence normal. NA, not applicable.

DNA preparation. Genomic DNA was purified from peripheral blood using the Applied Biosystems (Foster City, CA) DNA extractor.

Search for common mutations by restriction enzyme analysis. In our first report (9), mutations $1529 \mathrm{~A}, 1456 \mathrm{~T}$ and $1484 \mathrm{~T}$ seemed to occur more often than others in the U.S. Caucasian population. Therefore, patients from this ethnic group were initially screened for these mutations.

Single-stranded conformation polymorphism and sequence analysis. When the more common mutations were not found, single-stranded conformation polymorphism analysis (13) of the coding region, and not

\section{PKLR gene}

$\mathbf{a}$

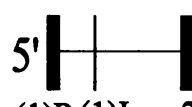

(1)R(1)L 2

b

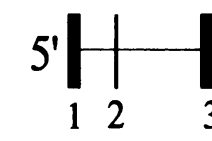

$1 \mathrm{~Kb}$

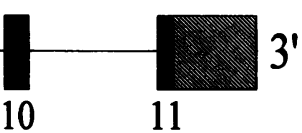

3' Figure 1. The PKLR gene. The closed boxes represent the exons, the shaded boxes represent the non-coding region. $a$ shows the nomenclature that we used previously for the exons of the $P K L R$ gene (9). 1(R) is the first exon of the red blood cell cDNA, 1(L) is the first exon of the liver cDNA. $b$ shows the nomenclature employed in this paper, numbering each exon consecutively. 
Table II. Oligonucleotides Used to Sequence the Introns 10 and 11 of the PKLR Gene

\begin{tabular}{ccccc}
\hline Intron & $\begin{array}{c}\text { Amplifying } \\
\text { oligonucleotides }\end{array}$ & \multicolumn{2}{c}{$\begin{array}{c}\text { Second amplifying or } \\
\text { sequencing oligonucleotides }\end{array}$} & $\begin{array}{c}\text { Amplifying } \\
\text { oligonucleotides }\end{array}$ \\
\hline 10 & $1 \mathrm{~F}$ & $2 \mathrm{~F}$ & $3 \mathrm{R}$ & $4 \mathrm{R}$ \\
10 & $1 \mathrm{~F}$ & $3 \mathrm{~F}$ & $2 \mathrm{R}$ & $4 \mathrm{R}$ \\
10 & $1 \mathrm{~F}$ & $4 \mathrm{~F}$ & $1 \mathrm{R}$ & $4 \mathrm{R}$ \\
10 & $1 \mathrm{~F}$ & $5 \mathrm{~F}$ & $3 \mathrm{R}$ & $4 \mathrm{R}$ \\
11 & $6 \mathrm{~F}$ & $7 \mathrm{~F}$ & $7 \mathrm{R}$ & $8 \mathrm{R}$ \\
11 & $6 \mathrm{~F}$ & $8 \mathrm{~F}$ & $6 \mathrm{R}$ & $8 \mathrm{R}$ \\
11 & $6 \mathrm{~F}$ & $9 \mathrm{~F}$ & $7 \mathrm{R}$ & $8 \mathrm{R}$ \\
11 & $6 \mathrm{~F}$ & $7 \mathrm{~F}$ & $5 \mathrm{R}$ & $8 \mathrm{R}$ \\
PKGypsy & $1 \mathrm{~F}$ & $5 \mathrm{~F}$ & $7 \mathrm{R}$ & $8 \mathrm{R}$ \\
PKGypsy & $1 \mathrm{~F}$ & $2 \mathrm{~F}$ & $5 \mathrm{R}$ & $8 \mathrm{R}$ \\
\hline
\end{tabular}

Designations refer to the underlined sequences shown in Fig 2. The sense strand was amplified with the oligonucleotides ending in F; oligonucleotides ending in $\mathbf{R}$ were used to amplify the antisense strand.

a (intron 10)

CTGAGGTCAC CGCCATTGGT GCTGTGGAGG CTGCCTTCAA GTGCTGTGCT GCTGCCATCA TTGTGCTGAC CACAACTGGC CGgtgagggg gatattggga atgtccagat ggagctttgg gtcaggggtg ggctgggacg ggcccaggc ttgggtttag tctggtcacc aggggtgaag agtgtccacc tgagacaaga ggagaggcag caatgacagc tggaggccag gagagacaga atgccagtga gcttctgggg getggaaggg gacagcggca tcactgggca cattggcttc aaggccattt gggcttctgg ggctcagagg caagtccatt cggcccacag agcctaccaa tactgaggta ttacagaagg gtccagtagg tctgagttta agtctttact cagaaatgta gctctattag cctgctctct ttcctcatga acaggacaag gtaatgattt gttcttcatg gggttggcag gattaacagg agatattaag tactagatag tacttaatat ctatatagta aattaagcac ataatggact ttctcaaaag ggttttatac tcttgggttt ttgtttgttt gttttgttt gtttttcttt tgagaacggc agctcgctct gttgctcagg ctggagtaaa atggtgcaat ctcagctcac cacaaccttc acctcccaag ttcaagtgat tctcctgcct cagccttccg agtagctggg attacaggcg catgccacaa cgccetgcat attttttgta tttttagtag agacagggtt tcatcatgtt agccaggctg gtctcaaact cctgacctca ggtgatccac cctccttggc ctccaaagt gctgggatta taggcatgag ccactgtgcc tggccagctt ttatatttct taaagagatt tctccttatt atctcatttg atatatctgt attatctcat atctttcttg tgtggtaggg agggcaggca ttcttectt tettetttt tttttctta atgcagagat ggggtctcac tatgttgcct aggctggtct ccagctcctg ggctcaaaca attctcccat ctcggectcc caaagtgctg ggattacagg catgagccac cgctcccggc ctgggaggca ggcattctta cactcatttt acaggtgaga acaccaaggc ccagagaagt atgatgactt acccagggtc acacagcttg ttagtgacac ctggaactgg aacaaagatt ctcctttcct cgttcaccac tttcttgctg ttctgggetg accttctctg cctcctccag CTCAGCCCAG CTTCTGTCTC GGTACCGACC TCGGGCAGCA GTCATTGCTG TCACCCGCTC TGCCCAGGCT

Figure 2. Sequence of introns $10(a)$ and $11(b)$. Exon sequences are in uppercase letters, intron sequences are in lowercase letters. Oligonucleotides listed in Table II are underlined. The bold sequence in $b$ represents the microsatellite identified by Lenzner et al (16), here shown with 12 ATT repeats. The approximate region of the Alu sequence is italicized. including the promoter, was performed, followed by direct sequencing of the coding region of exons in which band shifts were observed (9). Direct sequencing was carried out on DNA of the remaining patients until mutations were identified.

Sequencing of intron 10 and intron 11 was carried out to determine the boundaries of the putative deletion in the PKLR gene of patients 6 , 9, and 29, where exon 11 was missing. This was done using the oligonucleotides listed in Table II and shown in Fig. 2.

Confirmation of the mutations by restriction enzyme analysis. All the mutations were confirmed using restriction enzyme analysis except for the PK Gypsy. When a new mutation did not create or destroy a restriction endonuclease site a mismatched oligonucleotide primer that created an informative restriction site was made in order to confirm the mutation. Oligonucleotides and the restriction endonucleases used are listed in Table III.

Determination of the polymorphic sites. Two polymorphic sites were studied in all the patients to better understand the origin of the mutations. The polymorphic site at nt 1705 (14) was examined using restriction enzyme analysis as previously reported (15). A microsatellite (variable number tandem repeat), recently identified in intron 11 by Lenzner et

b (intron 11)

GGTCCACTTA TGCCGAGGAG TCTTCCCCTT GCTTTACCGT GAACCTCCAG $\frac{\text { AAGCCATCTG GGCAGATGAT GTAGATCGCC GGGTGCAATT TGGCATTGAA }}{7 \mathrm{~F}}$ AGTGgtgagc tacctagacc ttccctgcca ctcctaccat ttgtatcagg agccccccaa cccagcttcc catacccact caaagggect tgcctctctc ctgtggtcce aggttttccc tgtgagagtc actaagactg agatatcagt ggcgtgctac ttagcaacac actctgccet agcccacaga tactcctgca $8 \mathrm{~F}$ ccttttttt ttttgagag agagtcttgc tctgtcgcca ggctggagtg caggggtacg atctcggctc actgcaatct ctgcctcctg ggttcaagtg attctcccac ctcagcctcc tgagtagctg ggactacagg catgcgccac cacgcctgga taatttttgt attttagta gagacagggt ttcaccatgt tggccaggat ggtctcaatg tcttgaccac gtgatccgcc cgcctcggac tcccagagtg ctgggattac aggcgtcagc caccgtgctg gcatctctta cacctttaat atactgcagt ggtcacattc cctgcatgcc acccgtggga

catacttcac tgcctcattc cctacaggat ggccttgatg tggtgaaagg tggtggctgg ttctcgttac agggctggcc tggtccctca atgactaatt ttcttcttt tcttcttta trattattat tattattatt attattatta ttattttgag atggagtctt getctgtccc caggetggag tgcagtggtg tgatctcggc tcactgcaac ctctacctcc tgagttcaag cgattctcct gcctcagcet ccctagtagc tgggattaca ggcatgcgcc accacaccca gctaatttt gtattttcag tagagacaag tttcaccatg ttggccaggc tggtctcaaa ctcctgacct caggtgatcc tcctgccttg gcttcccaaa gtgatgggat tacaggtgtg agccaccaca cctgtccaat gatttgtttt ctttccctcc cccagGAAAG CTCCGTGGCT TCCTCCGTGT TGGAGACCTG

GTGATTGTGG TGACAGGCTG GCGACCTGGC TCCGGCTACA C ctggcatatc acaatacct cttccatcag catagccaca caggcagacg 
Table III. Oligonucleotides and Restriction Enzymes Used to Detect the Mutations in the PKLR Gene

\begin{tabular}{|c|c|c|c|c|c|c|c|}
\hline Mutation & Exon & $\begin{array}{c}\text { Sense } \\
\text { oligonucleotide }\end{array}$ & $\begin{array}{c}\text { Antisense } \\
\text { oligonucleotide }\end{array}$ & Size of PCR fragments & Enzyme & Size of normal fragments & Size of mutated fragments \\
\hline 307C del & 4 & A & B & 78 nor. -77 mut. & StuI+ & 78 & $23+54$ \\
\hline 391-393 del & 5 & $\mathrm{C}$ & D & 232 nor. -229 mut. & MwoI+ & $9+223$ & $9+64+156$ \\
\hline $401 \mathrm{~T} \rightarrow \mathrm{A}$ & 5 & $\mathrm{C}$ & D & 232 & BsiEI+ & 232 & $78+154$ \\
\hline $464 \mathrm{~T} \rightarrow \mathrm{C}$ & 5 & $\mathrm{C}$ & D & 232 & NciI+ & $79+153$ & $60+79+93$ \\
\hline $721 \mathrm{G} \rightarrow \mathrm{T}$ & 7 & E & $\mathrm{F}$ & 411 & "AfIIII+", & 411 & $17+394$ \\
\hline $808 \mathrm{C} \rightarrow \mathrm{T}$ & 7 & E & F & 411 & DdeI+ & 411 & $108+303$ \\
\hline $993 \mathrm{C} \rightarrow \mathrm{A}$ & 7 & $\mathrm{E}$ & $\mathrm{F}$ & 411 & "'StuI+", & 411 & $19+392$ \\
\hline $1022 \mathrm{G} \rightarrow \mathrm{C}$ & 8 & G & $\mathbf{H}$ & 252 & StyI- & $101+151$ & 252 \\
\hline $1076 \mathrm{G} \rightarrow \mathrm{A}$ & 8 & G & $\mathbf{H}$ & 252 & HhaI- & $92+160$ & 252 \\
\hline $1089 \mathrm{G} \rightarrow \mathrm{GG}$ & 8 & G & $\mathbf{H}$ & 252 nor. -253 mut. & MwoI+ & 252 & $76+177$ \\
\hline $1178 \mathrm{~A} \rightarrow \mathrm{G}$ & 9 & I & $\mathbf{J}$ & 289 & BsrIt+ & $94+195$ & $45+94+150$ \\
\hline $1179 \mathrm{~T} \rightarrow \mathrm{A}$ & 9 & I & J & 289 & AluI+ & $5+12+126+146$ & $5+12+50+96+126$ \\
\hline $1373 G \rightarrow A$ & 10 & $\mathbf{K}$ & $\mathbf{L}$ & 181 & SfaNI+ & 181 & $38+143$ \\
\hline $1378 \mathrm{G} \rightarrow \mathrm{A}$ & 10 & $\mathbf{K}$ & $\mathbf{L}$ & 181 & "NsiI+" & 181 & $18+163$ \\
\hline $1456 \mathrm{C} \rightarrow \mathrm{T}$ & 11 & $\mathbf{M}$ & $\mathbf{N}$ & 326 & BsmAI- & $73+253$ & 326 \\
\hline $1484 \mathrm{C} \rightarrow \mathrm{T}$ & 11 & $\mathbf{M}$ & $\mathbf{N}$ & 326 & MwoI- & $25+68+96+137$ & $68+121+137$ \\
\hline $1493 \mathrm{G} \rightarrow \mathrm{A}$ & 11 & $\mathbf{M}$ & $\mathbf{N}$ & 326 & BsrBI- & $109+217$ & 326 \\
\hline $1529 \mathrm{G} \rightarrow \mathrm{A}$ & 11 & $\mathbf{M}$ & $\mathbf{N}$ & 326 & StyI+ & 326 & $143+183$ \\
\hline \multicolumn{5}{|c|}{ Sense oligonucleotides } & \multicolumn{2}{|c|}{ Antisense oligonucleotides } & \\
\hline \multicolumn{5}{|c|}{$\mathrm{A}=$ 5' $^{\prime}$-GCCAGCATCTCGCTCCGTGG-3' } & \multicolumn{3}{|c|}{$\mathrm{B}=$ 5' $^{\prime}$-TGGGAGAAGTTGAGTCGCGC-3' } \\
\hline \multicolumn{5}{|c|}{ 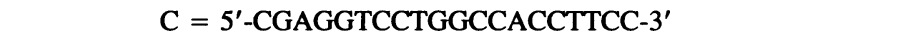 } & \multicolumn{3}{|c|}{$\mathrm{D}=5^{\prime}-\mathrm{GCGCCGCCTTTCCGGCCCTG-3^{ \prime }}$} \\
\hline \multicolumn{5}{|c|}{$\mathrm{E}=5^{\prime}$-GAGGGACTGGTGACCCACGT-3' } & \multicolumn{3}{|c|}{$\mathrm{F}=5^{\prime}-\mathrm{CCCCCGTGCCACCATGAGGC-3^{ \prime }}$} \\
\hline \multirow{2}{*}{\multicolumn{5}{|c|}{$\mathrm{G}=5^{\prime}$-CACCTTTCTTCTCCTGCCTG-3' }} & \multicolumn{3}{|c|}{$\mathrm{H}=5^{\prime}-\mathrm{CAGGTGTCCCTAAAACCCAC-3^{ \prime }}$} \\
\hline & & & & $\mathrm{I}=5^{\prime}-$ GATTACCAAGCCCCGGTCAA- $3^{\prime}$ & \multicolumn{3}{|c|}{$\mathbf{J}=5^{\prime}-$ CGTAGCTCCTCAAACAGCTG-3' } \\
\hline \multicolumn{5}{|c|}{$\mathrm{K}=5^{\prime}$-CCTTCCATACCCCAGTGCCC-3' } & \multicolumn{3}{|c|}{$\mathrm{L}=5^{\prime}-\mathrm{CAGCACTTGAAGGCAGCATGCA-3^{ \prime }}$} \\
\hline \multicolumn{5}{|c|}{$\mathrm{M}=$ 5' $^{\prime}$-CTCGTTCACCACTTTCTTGC-3' } & \multicolumn{3}{|c|}{$\mathrm{N}=5^{\prime}$-GAGGCAAGGCCCTTTGAGTG-3' } \\
\hline
\end{tabular}

The bold font in the oligonucleotides represents a mismatched nucleotide. Quotes indicate that an artificial restriction site has been introduced by using a mismatched oligonucleotide.

al (16) (see Fig. 2), was examined in the normal population and in the patients according to the procedure described by Lenzner et al (16) using the oligonucleotides 5'-GGCTGGTTCTCGTTACAG-3', and 5'GGAGAATCGCTTGAACTCAG-3' and the PCR buffer described by Kogan et al. (17).

Studies of cDNA prepared from reticulocytes of patients with the putative exon 11 deletion. Whole blood was passed through a column of microcrystalline cellulose and $\alpha$-cellulose (Sigma Chem. Co., St. Louis, MO) to remove leukocytes and platelets (18). Reticulocytes

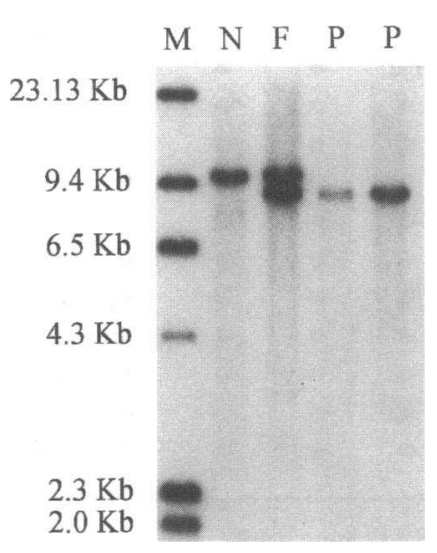

Figure 3. Detection of the PK Gypsy deletion by restriction analysis and Southern blotting of the PKLR gene. $M$, marker ${ }^{32} \mathrm{P}$-labeled $\lambda$ DNA-HindIII digest; $N$, normal subject; $F$, father of patient $6 ; P$, patient 6 . The father's DNA shows two distinct bands. The top band is also present in DNA from the normal subject and represents a 10-kb fragment obtainable with an EcoRI digestion. The lower band is present in DNA from the patient and the different size is due to the missing portion of the gene. were isolated by centrifugation through a Percoll gradient (19). Total RNA was extracted from the reticulocytes using Trizol Reagent (total RNA isolation reagent. GIBCO BRL, Gaithersburg, MD). First strand cDNA was made from the total RNA, using oligo(dT) and reverse transcriptase as described (20). DNA extending from cDNA nt 1362 to cDNA nt 1694 was amplified by 35 PCR cycles using $250 \mathrm{ng}$ of sense oligonucleotide 5'-CACCGCCATTGGTGCTGTGG-3' and antisense 5'-GTGTAGCCGGAGCCAGGTCG-3'. The PCR product was purified with phenol/chloroform, ethanol-precipitated and redissolved in water. The approximate size of the PCR product was established by electrophoresis in a $10 \%$ polyacrylamide gel using molecular marker (pBR322 DNA MspI digest) after staining with ethidium bromide. The same PCR product was also sequenced with the fmol DNA Sequencing

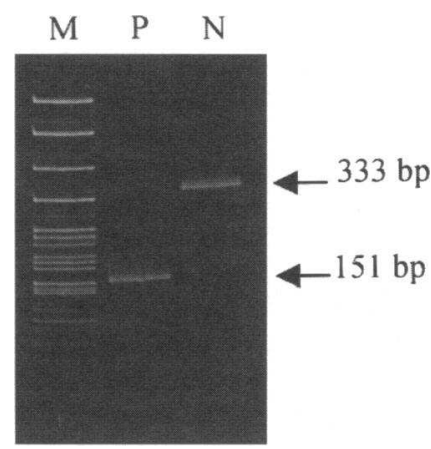

Figure 4. Detection of the deletion of exon 11 in the mRNA of the Gypsy patient. $M$, marker pBR322 DNA-MspI digest; $P$, patient $9 ; N$, normal subject. The size difference of the two fragments ( 333 bp normal and 151 bp patient 9) obtained from the similar PCR is due to the absence of exon 11 ( $182 \mathrm{bp}$ ) in the patient. 


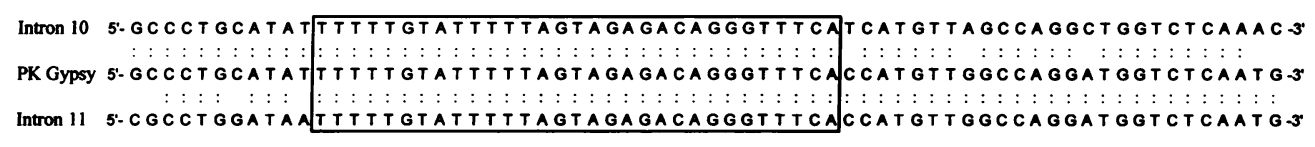

Figure 5. Nucleotide sequences across the deletion junction of the PK Gypsy and corresponding intron 10 and intron 11 sequences of the normal gene. The area of the crossing over is in the box. Dots denote matches between the three sequences.
System (Promega Corp. Madison, WI) using two end-labeled primers $5^{\prime}$ - CTGCCTTCAAGTGCTGTGCT - $3^{\prime}$ and $5^{\prime}$ - CACCACAATCAC CAGGTCTC-3'.

Restriction analysis and Southern blotting of the PKLR gene. A PCR fragment of 1101 base pairs made from R-type cDNA extending from nt 702 to nt 1802 served as a probe in Southern blotting studies. The probe was labeled with $\left[{ }^{32} \mathrm{P}\right] \mathrm{dATP}$ using a Stratagene Inc. (La Jolla, CA) Prime-it Random Primer Kit. The electrophoresis and Southern blot were performed using the Neat System (Oncor Inc., Gaithersburg, MD). $10 \mu \mathrm{g}$ of genomic DNA were incubated with 300 units of EcoR I (New England Biolabs, Beverly, MA) at $37^{\circ} \mathrm{C}$ overnight to ensure complete digestion. After electrophoresis in $0.7 \%$ agarose for $16 \mathrm{~h}$ at $3.3 \mathrm{~V} / \mathrm{cm}$, the DNA was transferred to a nylon membrane (Sure Blot., Oncor Inc.) and hybridized in $10 \%$ Dextran Sulfate, $50 \%$ deionized formamide, $1 \%$ SDS, $200 \mu \mathrm{g} / \mathrm{ml}$ denatured sonicated/sheared salmon sperm DNA and $900 \mathrm{mM} \mathrm{NaCl}$ with $\sim 1 \mu \mathrm{Ci}$ of probe per $100 \mathrm{~cm}^{2}$ of filter at $42^{\circ} \mathrm{C}$ overnight. It was washed with $0.1 \times \mathrm{SSC}$ and $0.1 \%$ SDS at $55^{\circ} \mathrm{C}$, and visualized using XAR $x$-ray film. ${ }^{32} P$-labeled HindIII digest of $\lambda$ DNA provided size markers.

\section{Results}

Mutations. The mutations present in the thirty patients are summarized in Table I. In two patients the second mutation could not be found in the coding region.

Three patients of gypsy extraction appeared to be homozygous for the same mutation. It was designated PK Gypsy. The first evidence that a unique, homozygous mutation existed in these patients was found by PCR. We were able to amplify exons 10 and 12 but not exon 11 (data not shown). Southern blotting revealed a major deletion in the PKLR gene estimated to be over $1 \mathrm{~kb}$ in size. Fig. 3 is a Southern blot that shows that patient 6 is homozygous for this deletion and that the father is heterozygous. Fig. 4 shows the size of the PCR products made using total RNA from patient 9 and from a normal subject. The size difference in this cDNA fragment is $\sim 182 \mathrm{bp}$, the length of exon 11. Subsequent sequencing of these two PCR fragments confirmed these observations. Using the oligonucleotides shown in Table II we were able to determine the sequence

Table IV. Population Frequency of the Intron 11 Microsatellite ATT Repeat of the PKLR Gene in 50 Subjects of European Origin

\begin{tabular}{cc}
\hline ATT repeat numbers & Population Frequency \\
\hline 12 & 0.16 \\
13 & 0.05 \\
14 & 0.49 \\
15 & 0.19 \\
16 & 0.05 \\
17 & 0.03 \\
18 & 0.02 \\
19 & 0.01 \\
\hline
\end{tabular}

of introns 10 and 11 (see Fig. 2) in a normal subject and in the Gypsy patients. Fig. 5 illustrates the sequence beginning in intron 10 and skipping to intron 11 . This deletion, $1149 \mathrm{bp}$ in length, caused the absence of exon 11 in the mRNA resulting in a subsequent frameshift.

Polymorphisms. Table I documents the polymorphisms at nt 1705 and at the microsatellite ATT repeat in intron 11 in these patients. The allele frequency of the intron 11 microsatellite in the Caucasian population was estimated by a study of 100 chromosomes of unrelated subjects. Eight different sequences were identified among the 50 individuals examined, the sequence containing the 14 ATT repeats was found to be the most common (see Table IV). Six homozygotes for the 1529A mutation all manifest the C/C genotype at nt 1705 and the 14/ 14 genotype at the microsatellite. The seventh homozygous patient (23) had a C/C genotye but a 14/15 genotype. The genotype was confirmed by study of the patient's parents. In seven patients heterozygous for the $1529 \mathrm{~A}$ mutation at least one 14 repeat was present in each patient.

\section{Discussion}

Among the 60 alleles at risk in the 30 PK deficient patients studied, 58 mutations were found in the coding region. Although it is possible that a mutation was present and was missed for technical reasons, these mutations may represent substitutions in the promoter region, in the $3^{\prime}$ untranslated region (affecting mRNA stability), or in an intron, creating a new splice site.

Table V. Conservation of Amino Acids among Several Species

\begin{tabular}{|c|c|c|c|c|c|c|}
\hline \multirow[b]{3}{*}{ Mutation } & \multirow{3}{*}{$\begin{array}{l}\text { Amino acid } \\
\text { substitution }\end{array}$} & \multicolumn{5}{|c|}{ Species } \\
\hline & & \multicolumn{5}{|c|}{ Isoenzyme } \\
\hline & & $\mathbf{R}$ & M2 & M1 & M1 & $\mathbf{R}$ \\
\hline $401 \mathrm{~T} \rightarrow \mathrm{A}$ & $134 \mathrm{Val} \rightarrow$ Asp & - & $\bullet$ & - & Ile & Ala \\
\hline $464 \mathrm{~T} \rightarrow \mathrm{C}$ & 155Leu $\rightarrow$ Pro & $\bullet$ & $\bullet$ & $\bullet$ & $\bullet$ & $\bullet$ \\
\hline $993 \mathrm{C} \rightarrow \mathrm{A}$ & 331 Asp $\rightarrow$ Glu & Tyr & $\bullet$ & $\bullet$ & $\bullet$ & $\bullet$ \\
\hline $1022 \mathrm{G} \rightarrow \mathrm{C}$ & $341 \mathrm{Gly} \rightarrow \mathrm{Ala}$ & $\bullet$ & - & • & - & $\bullet$ \\
\hline $1076 \mathrm{G} \rightarrow \mathrm{A}$ & 359Arg $\rightarrow$ His & $\bullet$ & $\bullet$ & $\bullet$ & $\bullet$ & Lys \\
\hline $1178 \mathrm{~A} \rightarrow \mathrm{G}$ & 393Asn $\rightarrow$ Ser & - & - & $\bullet$ & - & $\bullet$ \\
\hline $1179 \mathrm{~T} \rightarrow \mathrm{A}$ & 393Asn $\rightarrow$ Lys & $\bullet$ & $\bullet$ & $\bullet$ & $\bullet$ & $\bullet$ \\
\hline $1373 \mathrm{G} \rightarrow \mathrm{A}$ & 458Gly $\rightarrow$ Asp & $\bullet$ & $\bullet$ & $\bullet$ & - & Pro \\
\hline $1378 \mathrm{G} \rightarrow \mathrm{A}$ & $460 \mathrm{Val} \rightarrow \mathrm{Met}$ & $\bullet$ & $\bullet$ & $\bullet$ & $\bullet$ & $\bullet$ \\
\hline $1456 \mathrm{C} \rightarrow \mathrm{T}$ & 486Arg $\rightarrow \operatorname{Trp}$ & $\bullet$ & $\bullet$ & $\bullet$ & Gln & Lys \\
\hline $1484 \mathrm{C} \rightarrow \mathrm{T}$ & 495Ala $\rightarrow$ Val & $\bullet$ & $\bullet$ & - & $\bullet$ & Leu \\
\hline $1493 \mathrm{G} \rightarrow \mathrm{A}$ & 498Arg $\rightarrow$ His & $\bullet$ & $\bullet$ & $\bullet$ & $\bullet$ & $\bullet$ \\
\hline $1529 \mathrm{G} \rightarrow \mathrm{A}$ & 510Arg $\rightarrow$ Gln & - & - & - & - & - \\
\hline
\end{tabular}

The black dot represents the conserved amino acids. 


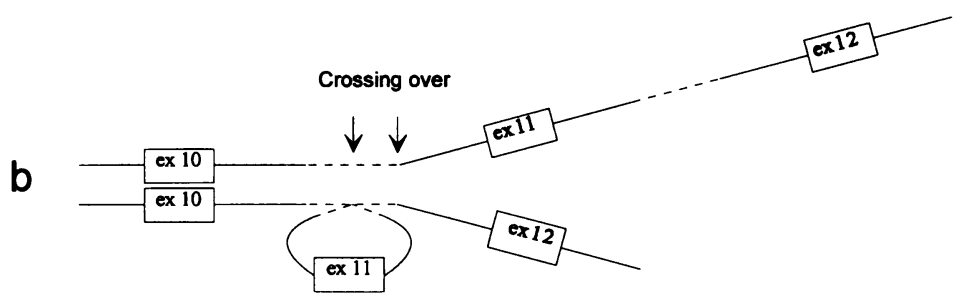

C

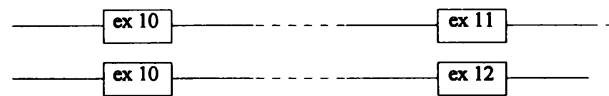

Figure 6. Schematic representation of misaligned chromatids before crossover. This may cause the PK Gypsy deletion. $a$ shows the two chromatids. The broken line represents the two regions with high homology located in intron 10 and in intron $11 . b$ shows the misalignment of the two chromatids. Any crossover in the region between the arrows will result in a loss of exon 11 in one chromatid and the acquisition of exon 11 in the other as shown in $c$.
We found 19 different mutations among the 58 PK mutations identified. Five of these cause either a stop codon or a frameshift and are therefore undoubtedly the cause of the deficiency. One mutation causes the deletion of an amino acid, which presumably results in the enzyme deficiency. However, the cause-andeffect relationship between a single amino acid substitution and the enzyme defect is less certain. Whenever a new nucleotide substitution was found, the whole coding region was sequenced. If no other nucleotide substitution was found we considered the mutation we had detected to be the cause of the deficiency. We also compared the mutated triplets with the corresponding PK amino acid sequence in other species. Each of the 12 mutated amino acids was one that was well conserved among the species examined, further strengthening the presumption that the change would decrease enzyme activity (Table V).

Of the 12 amino acids changes documented, only a few are correlated with the putative binding site determined by crystallographic studies of the cat muscle PK (21). The 464C mutation changes one of the amino acids located in the domain $\mathrm{A}$ in the $\beta$-sheet 3 , the $993 \mathrm{~A}$ and $1022 \mathrm{C}$ mutations change the amino acids close to the binding site located in the A domain $\beta$-sheet 6 and $\alpha$-helix 6 . Significantly, 5 of the 8 mutations that are in domain $\mathrm{C}$, believed to play a role in intersubunit contacts, involve loss of arginine residues and could cause enzyme instability by weakening salt bridges that hold the subunits together. These and the remaining mutations may make the enzyme more vulnerable to proteolysis, explaining the reduced quantity of red cell PK antigen in some patients (22). Alternatively, they may be at other sites that are proximate to the active sites of the enzyme in its three dimensional structure.

Since heterozygotes for PK deficiency have no known selective advantage, we might have expected that most cases would be represented by new mutations rather than selection of one particular mutation. In 1993 we first reported that we found one mutation, 1529A, to be more common than the others in a group of 10 patients (9), an observation that has recently been confirmed by Lenzner et al. (23). This mutation occurred a disproportionate twenty-five times in our 30 patients and represents $41.6 \%$ of all the alleles studied. This mutation always seems to be associated with a cytosine at the polymorphic site at nt 1705 and with a single exception (patient 23) with the 14 ATT repeat in the microsatellite, located in intron 11. Lenzner has also observed (personal communication) the same haplotype in association with the 1529A mutation in the European population. These findings suggest a single origin of this mutation, a finding that is compatible with the existence of the 1529A mutation as a balanced polymorphism. Other mutations also were present more than once: $1456 \mathrm{~T}$ five times, 1486T three times, 1378A three times, and 721T three times. Patient 28 was homozygous for the 1378A mutation. Since the frequency of this mutation is low it is likely that either the parents of patient 28 are related or this mutation is more common in the Hispanic population than in the European population. It is notable that all of these mutations appear to be always in the same haplotype. There is only one case that is not consistent with this observation. In patient 8 the $1456 \mathrm{~T}$ mutation was found both with the 15 or the 16 ATT repeat rather than the 14ATT repeat. This situation, as in the case of patient 23 , could be explained by the fact that the microsatellites seem to be unstable and that a change occurred in these chromosomes after the original mutation arose. Alternatively, the association of these mutations with a different haplotype could be the result of a crossover in one of the patients' ancestors. The fact that these mutations, particularly 1529A, seem to have a single origin can best be explained by a possible advantage for the heterozygote and, as we suggested in the past (24), the advantage could be that the high concentration of 2,3-bisphosphoglycerate in carrier erythrocytes reduces erythrocyte oxygen affinity.

PK Gypsy is the mutation that results in the most severe damage to the $P K L R$ gene. If any protein survives intracellular proteolysis, the $\mathrm{C}$ domain, which seems to be responsible for the inter-subunit contact, would be missing. We would expect any residual protein to have a very low activity and it is possible that, as has already been reported by others $(23,25)$, the activity that is observed is due to expression of M2 isoenzyme, not the mutant $\mathbf{R}$ isoenzyme. PK Gypsy probably originated from a misalignment of the two alleles during crossing over in meiosis, as has been described frequently (26-29). We found two regions in intron 10 and 11 that are nearly identical, both matching an Alu sequence, and that might have caused this misalignment of the two chromatids. Fig. 6 shows how an unequal crossover would result in two different products: one from which exon 11 is absent and one where two exon 11's are present. There is no doubt that this mutation has a single origin and this is confirmed by the fact that we found the six PK Gypsy alleles always to be in the same haplotype.

Since PK deficiency can be a devastating disease, parents who already have an affected child often request prenatal diag- 
Table VI. Mutations Known to Cause Pyruvate Kinase Deficiency

\begin{tabular}{|c|c|c|c|c|c|c|}
\hline Name & $\begin{array}{l}\text { cDNA number from } \\
\text { upstream ATG }\end{array}$ & $\begin{array}{c}\text { Base } \\
\text { substitution }\end{array}$ & $\begin{array}{l}\text { Amino acid } \\
\text { number }\end{array}$ & $\begin{array}{l}\text { Amino acid } \\
\text { substitution }\end{array}$ & Exon & Reference \\
\hline$*$ & $\operatorname{Ivs} 3(-1)$ & $\mathrm{g} \rightarrow \mathrm{a}$ & Not applicable & Not applicable ${ }^{\ddagger}$ & Ivs3 & $(23)$ \\
\hline$*$ & 307 & $\mathrm{C} \rightarrow \mathrm{Del}$ & Not applicable & Not applicable ${ }^{\S}$ & 4 & This paper \\
\hline$*$ & $391,392,393$ & ATC $\rightarrow$ Del & 131 & Ile $\rightarrow$ Del & 5 & (9) \\
\hline$*$ & 401 & $\mathrm{~T} \rightarrow \mathrm{A}$ & 134 & $\mathrm{Val} \rightarrow$ Asp & 5 & (9) \\
\hline$*$ & 464 & $\mathrm{~T} \rightarrow \mathrm{C}$ & 155 & Leu $\rightarrow$ Pro & 5 & (9) \\
\hline Linz & 487 & $\mathrm{C} \rightarrow \mathrm{T}$ & 163 & Arg $\rightarrow$ Cys & 5 & (32) \\
\hline$*$ & 721 & $G \rightarrow T$ & 241 & Glu $\rightarrow$ End & 7 & (9) \\
\hline$*$ & 808 & $\mathrm{C} \rightarrow \mathrm{T}$ & 270 & Arg $\rightarrow$ End & 7 & This paper \\
\hline Hong Kong & 941 & $\mathrm{~T} \rightarrow \mathrm{C}$ & 314 & $\mathrm{Ile} \rightarrow \mathrm{Thr}$ & 7 & $(34)$ \\
\hline Kowloon & Ivs7 (+1) & $g \rightarrow t$ & Not applicable & Not applicable ${ }^{\ddagger}$ & Ivs7 & (34) \\
\hline$*$ & 993 & $\mathrm{C} \rightarrow \mathrm{A}$ & 331 & Asp $\rightarrow$ Glu & 8 & This paper \\
\hline$*$ & 994 & $\mathrm{G} \rightarrow \mathrm{A}$ & 332 & Gly $\rightarrow$ Ser & 8 & (23) \\
\hline$*$ & 1006 & $\mathrm{G} \rightarrow \mathrm{T}$ & 336 & $\mathrm{Ala} \rightarrow \mathrm{Ser}$ & 8 & (23) \\
\hline$*$ & 1022 & $\mathrm{G} \rightarrow \mathrm{C}$ & 341 & Gly $\rightarrow$ Ala & 8 & This paper \\
\hline$*$ & $1060,1061,1062$ & $\mathrm{AAG} \rightarrow$ Del & 354 & Lys $\rightarrow$ Del & 8 & $(23)$ \\
\hline$*$ & 1076 & $\mathrm{G} \rightarrow \mathrm{A}$ & 359 & Arg $\rightarrow$ His & 8 & (9) \\
\hline$*$ & 1081 & $A \rightarrow G$ & 361 & Asn $\rightarrow$ Asp & 8 & (23) \\
\hline * & 1089 & $\mathrm{G} \rightarrow \mathrm{GG}$ & Not applicable & Not applicable ${ }^{\S}$ & 8 & This paper \\
\hline Osaka & 1102 & $\mathrm{G} \rightarrow \mathrm{T}$ & 368 & Val $\rightarrow$ Phe & 8 & $(25)$ \\
\hline \multicolumn{7}{|c|}{ Tokyo, Beirut, } \\
\hline Nagasaki & 1151 & $\mathrm{C} \rightarrow \mathrm{T}$ & 384 & Thr $\rightarrow$ Met & 9 & $(8,14,32)$ \\
\hline$*$ & 1174 & $\mathrm{G} \rightarrow \mathrm{A}$ & 392 & Ala $\rightarrow$ Thr & 9 & (23) \\
\hline$*$ & 1178 & $A \rightarrow G$ & 393 & Asn $\rightarrow$ Ser & 9 & This paper \\
\hline$*$ & 1179 & $\mathrm{~T} \rightarrow \mathrm{A}$ & 393 & Asn $\rightarrow$ Lys & 9 & This paper \\
\hline$*$ & 1203 & $\mathrm{C} \rightarrow \mathrm{CAGC}$ & Not applicable & Cys $\rightarrow$ CysSer & 9 & $(23)$ \\
\hline \multicolumn{7}{|l|}{ Fukushima, } \\
\hline Sendai & 1261 & $\mathrm{C} \rightarrow \mathrm{A}$ & 421 & Gln $\rightarrow$ Lys & 9 & (14) \\
\hline Saporo & 1277 & $\mathrm{G} \rightarrow \mathrm{A}$ & 426 & $\operatorname{Arg} \rightarrow$ Gln & 10 & (33) \\
\hline$*$ & 1373 & $G \rightarrow A$ & 458 & Gly $\rightarrow$ Asp & 10 & This paper \\
\hline * & 1378 & $\mathrm{G} \rightarrow \mathrm{A}$ & 460 & $\mathrm{Val} \rightarrow \mathrm{Met}$ & 10 & This paper \\
\hline Amish & 1436 & $\mathrm{G} \rightarrow \mathrm{A}$ & 479 & Arg $\rightarrow \mathrm{His}^{\ddagger}$ & 10 & $(35)$ \\
\hline Gypsy & $1437-1618$ & $182 \mathrm{nt}$ Del & Not applicable & Not applicable & 11 & This paper \\
\hline$*$ & 1456 & $\mathrm{C} \rightarrow \mathrm{T}$ & 486 & $\operatorname{Arg} \rightarrow \operatorname{Trp}$ & 11 & (9) \\
\hline * & 1484 & $\mathrm{C} \rightarrow \mathrm{T}$ & 495 & $\mathrm{Ala} \rightarrow \mathrm{Val}$ & 11 & (9) \\
\hline$*$ & 1493 & $\mathrm{G} \rightarrow \mathrm{A}$ & 498 & Arg $\rightarrow$ His & 11 & This paper (23) \\
\hline$*$ & 1529 & $\mathrm{G} \rightarrow \mathrm{A}$ & 510 & Arg $\rightarrow$ Gln & 11 & $(9,23)$ \\
\hline * & 1594 & $\mathrm{C} \rightarrow \mathrm{T}$ & 532 & Arg $\rightarrow$ Trp & 11 & (23) \\
\hline
\end{tabular}

* The variant has no name. ${ }^{\ddagger}$ Splice site. ${ }^{\S}$ Frameshift. " Deletion of 60 amino acids and frameshift.

nosis. In the past we had the opportunity to make a diagnosis during a second pregnancy, for the parents of patient 20 . In this case the mutations present in the affected child were already known therefore we could establish the diagnosis by direct analysis of the fetal DNA (30). When mutations that affect a family are not known, analysis of polymorphisms linked with the $P K L R$ gene provides a helpful alternative. For this purpose the microsatellite reported by Lenzner et al (16) can be very useful. In our study of a normal Caucasian population we found eight different alleles at this locus. Even though some of these alleles are fairly common, using this marker along with the polymorphism at nt $1705 \mathrm{~A} / \mathrm{C}$ of the PKLR gene (14) and the Pv1.1 polymorphism of the tightly linked glucocerebrosidase gene $(15,31)$ provides a greatly improved probability of obtaining an informative pedigree.

The number of PK mutations known, including the ones in this report, is now $35(8,9,11,14,23,25,32-35)$ (Table VI). Only three of these mutations have been detected by more than one group of investigators. Mutation 1151T was first found in the Japanese population (8) and soon after in a Lebanese family (32). Subsequent reports suggest that this mutation may be the most common in the Japanese population (14). Two other mutations initially documented by us and also found by others are the 1493A mutation which has been reported once as a heterozygote (23) and the 1529A mutation which has been found seven times in a group of 12 patients (23). The 1529A mutation was found in the same haplotype with respect to the polymorphic site at nt 1705 and the same low residual PK activity (23). During the last two years there has been a rapid increase of identified mutations that cause PK deficiency. The large number of mutations that we now know and in particular the high frequency of the 1529A mutation, are very useful for 
diagnosis, especially prenatal diagnosis and in transfusion-dependent patients.

\section{Acknowledgments}

The authors thank Drs. N. Dainiack, P. D. Mattson, C. L. Lutcher, E. M. Kurczynski, J. R. Priest, D. Williams, H. S. Bowman, P. Dal Borgo, R. Barr, N. Buist, W. Francombe, L. Hankerson, P. Groney, J. Finkelstein, S. Bottomley, M. Mieler, M. Etzl, A. Freeman, P. Parker, N. L. C. Luban, E. Bayar, D. M. Simonsen, J. Frost, J. Jones, M. Kaime, D. Dimichele, T. C. Green, and T. O'Connor for making samples available for study.

This is manuscript number 8828-MEM from The Scripps Research Institute. Supported by National Institutes of Health grants HL25552 and RR00833 and the Sam Stein and Rose Stein Charitable Trust Fund.

\section{References}

1. Miwa, S., H. Kanno, and H. Fujii. 1993. Pyruvate kinase deficiency: Historical perspective and recent progress of molecular genetics. Am. J. Hematol. 42:31 35 .

2. Noguchi, T., K. Yamada, H. Inoue, T. Matsuda, and T. Tanaka. 1987. The L- and R-type isozymes of rat pyruvate kinase are produced from a single gene by use of different promoters. J. Biol. Chem. 262:14366-14371.

3. Miwa, S., and H. Fujii. 1990. Pyruvate kinase deficiency. Clin. Biochem. 23:155-157.

4. Valentine, W. N., K. R. Tanaka, and S. Miwa. 1961. A specific erythrocyte glycolytic enzyme defect (pyruvate kinase) in three subjects with congenital nonspherocytic hemolytic anemia. Trans. Assoc. Am. Phys. 74:100-110.

5. Valentine, W. N., K. R. Tanaka, and D. E. Paglia. 1983. Pyruvate kinase and other enzyme deficiency disorders of the erythrocyte. In The Metabolic Basis of Inherited Disease. J. B. Stanbury, J. B. Wyngaarden, D. S. Fredrickson, J. L. Goldstein, and M. S. Brown, editors. McGraw-Hill, Inc. New York. 1606-1628.

6. Miwa, S., P. Boivin, K. G. Blume, H. Arnold, J. A. Black, A. Kahn, G. E. Staal, K. Nakashima, K. R. Tanaka, D. E. Paglia et al. 1979. Recommended methods for the characterization of red cell pyruvate kinase variants. Br. J. Haematol. 43:275-286.

7. Tani, K., H. Fujii, S. Nagata, and S. Miwa. 1988. Human liver type pyruvate kinase: complete amino acid sequence and the expression in mammalian cells. Proc. Natl. Acad. Sci. USA. 85:1792-1795.

8. Kanno, H., H. Fujii, A. Hirono, and S. Miwa. 1991. cDNA cloning of human R-type pyruvate kinase and identification of a single amino acid substitution $\left(\right.$ Thi $^{384} \rightarrow$ Met) affecting enzymatic stability in a pyruvate kinase variant (PK Tokyo) associated with hereditary hemolytic anemia. Proc. Natl. Acad. Sci. USA. 88:8218-8221.

9. Baronciani, L., and E. Beutler. 1993. Analysis of pyruvate kinase-deficiency mutations that produce nonspherocytic hemolytic anemia. Proc. Natl. Acad. Sci. USA. 90:4324-4327.

10. Baronciani, L., and E. Beutler. 1994. Analysis of pyruvate kinase (PK) mutations in patients with nonspherocytic hemolytic anemia. La Revista de Investigacion Clinica. 46(Suppl):187a.

11. Baronciani, L., and E. Beutler. 1993. Analysis of pyruvate kinase (PK) mutations that produce nonspherocytic hemolytic anemia. Blood. 82(Suppl 1):97a.

12. Beutler, E. 1984. Red Cell Metabolism: A Manual of Biochemical Methods. Grune \& Stratton, Inc. New York, NY. 2-179.

13. Orita, M., H. Iwahana, H. Kanazawa, K. Hayashi, and T. Sekiya. 1989.
Detection of polymorphisms of human DNA by gel electrophoresis as singlestrand conformation polymorphisms. Proc. Natl. Acad. Sci. USA. 86:2766-2770.

14. Kanno, H., H. Fujii, A. Hirono, M. Omine, and S. Miwa. 1992. Identical point mutations of the R-type pyruvate kinase (PK) cDNA found in unrelated PK variants associated with hereditary hemolytic anemia. Blood. 79:1347-1350.

15. Glenn, D., T. Gelbart, and E. Beutler. 1994. Tight linkage of pyruvate kinase $(P K L R)$ and glucocerebrosidase (GBA) genes. Hum. Genet. 93:635-638. 16. Lenzner, C., G. Jacobasch, A. Reis, B. Thiele, and P. Nürnberg. 1994. Trinucleotide repeat polymorphism at the PKLR locus. Hum. Mol. Genet. 3:523.

17. Kogan, S. C., M. Doherty, and J. Gitschier. 1987. An improved method for prenatal diagnosis of genetic diseases by analysis of amplified DNA sequences: application to hemophilia A. N. Engl. J. Med. 317:985-990.

18. Beutler, E., C. West, and K. G. Blume. 1976. The removal of leukocytes and platelets from whole blood. J. Lab. Clin. Med. 88:328-333.

19. Vettore, L., M. C. De Matteis, and P. Zampini. 1980. A new density gradient system for the separation of human red blood cells. Am. J. Hematol. 8:291-297.

20. Sorge, J., E. Gross, C. West, and E. Beutler. 1990. High level transcription of the glucocerebrosidase pseudogene in normal subjects and patients with Gaucher disease. J. Clin. Invest. 86:1137-1141.

21. Muirhead, H., D. A. Clayden, D. Barford, C. G. Lorimer, L. A. FothergillGilmore, E. Schiltz, and W. Schmitt. 1986. The structure of cat muscle pyruvate kinase. EMBO (Eur. Mol. Biol. Organ.) J. 5:475-481.

22. Kahn, A., J. Marie, C. Galand, and P. Boivin. 1975. Molecular mechanism of erythrocyte pyruvate kinase deficiency. Humangenetik. 29:271-280.

23. Lenzner, C., P. Nürnberg, B.-J. Thiele, A. Reis, V. Brabec, A. Sakalova, and G. Jacobasch. 1994. Mutations in the pyruvate kinase $L$ gene in patients with hereditary hemolytic anemia. Blood. 83:2817-2822.

24. Beutler, E. 1978. Hemolytic Anemia in Disorders of Red Cell Metabolism. Plenum Press, Inc. New York. 170 pp.

25. Kanno, H., H. Fujii, G. Tsujino, and S. Miwa. 1993. Molecular basis of impaired pyruvate kinase isozyme conversion in erythroid cells: a single amino acid substitution near the active site and decreased mRNA content of the R-type PK. Biochem. Biophys. Res. Commun. 192:46-52.

26. Myerowitz, R., and N. D. Hogikyan. 1987. A deletion involving Alu sequences in the beta-hexosaminidase alpha-chain gene of French Canadians with Tay-Sachs disease. J. Biol. Chem. 262:15396-15399.

27. Lehrman, M. A., D. W. Russell, J. L. Goldstein, and M. S. Brown. 1987. Alu-Alu recombination deletes splice acceptor sites and produces secreted low density lipoprotein receptor in a subject with familial hypercholesterolemia. $J$. Biol. Chem. 262:3354-3361.

28. Lehrman, M. A., J. L. Goldstein, D. W. Russell, and M. S. Brown 1987. Duplication of seven exons in LDL receptor gene caused by Alu-Alu recombination in a subject with familial hypercholesterolemia. Cell. 48:827-835.

29. Hobbs, H. H., M. S. Brown, J. L. Goldstein, and D. W. Russell. 1986 Deletion of exon encoding cysteine-rich repeat of low density lipoprotein receptor alters its binding specificity in a subject with familial hypercholesterolemia. $J$. Biol. Chem. 261:13114-13120.

30. Baronciani, L., and E. Beutler. 1994. Prenatal diagnosis of pyruvate kinase deficiency. Blood. 84:2354-2356.

31. Beutler, E., C. West, and T. Gelbart. 1992. Polymorphisms in the human glucocerebrosidase gene. Genomics. 12:795-800.

32. Neubauer, B., M. Lakomek, H. Winkler, M. Parke, S. Hofferbert, and W. Schröter. 1991. Point mutations in the L-type pyruvate kinase gene of two children with hemolytic anemia caused by pyruvate kinase deficiency. Blood. 77:18711875.

33. Kanno, H., H. Fujii, and S. Miwa. 1993. Low substrate affinity of pyruvate kinase variant (PK Sapporo) caused by a single amino acid substitution (426 $\mathrm{Arg} \rightarrow \mathrm{G} \ln$ ) associated with hereditary hemolytic anemia. Blood. 81:2439-2441.

34. Kanno, H., D. C. C. Wei, S. Miwa, L. C. Chan, and H. Fujii. 1993. Identification of a $5^{\prime}$-splice site mutations and a missense mutation in homozygous pyruvate kinase deficiency cases found in Hong Kong. Blood. 82(Suppl 1):97a.

35. Kanno, H., S. K. Ballas, S. Miwa, H. Fujii, and H. S. Bowman. 1994. Molecular abnormality of erythrocyte pyruvate kinase deficiency in the Amish. Blood. 83:2311-2316. 